\title{
Issues of National Security and Human Rights in Nigeria: A Case Study of Islamic Movement of Nigeria
}

\author{
Kenneth Nweke, Ph.D \\ Department of Political Science, \\ Ignatius Ajuru University of Education, \\ Rumuolumeni, P.M.B. 5047, Port Harcourt. \\ Eunice Etido-Inyang \\ Department of Political Science, \\ Ignatius Ajuru University of Education, \\ Rumuolumeni, P.M.B. 5047, Port Harcourt.
}

\begin{abstract}
This paper examined issues of national security and human rights in Nigeria with emphasis on the conflicts between the federal government and the Islamic Movement of Nigeria (IMN). The objectives of the paper included to determine the nature of national security and human rights in Nigeria vis-à-vis the Islamic Movement of Nigeria; identity the contentious issues that triggered the conflicts and undermined national security and human rights between the federal government and the Islamic Movement of Nigeria; determine the implications of continued crackdown of IMN members and detention of their leader, El-Zakzaky and his wife on national security and human rights violations in Nigeria, and make necessary recommendations on how these issues can be amicably resolved without compromising national security and human rights of Nigerians, especially IMN members. This research has become imperative in view of the continued detention of Sheikh Ibrahim El-Zakzaky by the security operatives in Nigeria since 2015 in spite of court orders without concluding the trials. This has caused great concern to Nigerians with daily debates on the implications of this prolonged incarceration of the duo on national security and human rights in a democratic system of government. This paper was anchored on the "Family Theory in Clinical Practice". The 'Family Theory' stressed the need to understand and consider the emotional functioning of a family or group as the basis for religious or political indoctrination, radicalisation, extremism and deviant behaviour that may be antagonistic to acceptable societal norms and values. This paper adopted descriptive research design. Data used for the study were gathered from secondary sources as content analysis was used in the interpretation of data. The paper found that the Islamic Movement of Nigeria (IMN) members were justified in their protest against military crackdown, detention and proscription. The paper observed that the over five year's detention of Sheikh ElZakzaky by the Nigerian government without trial amounts to the violation of his constitutionally guaranteed and legally protected human rights. This paper recommends the immediate and unconditional release of the Shiites leader from detention, speedy trial and respect for judicial pronouncements by the Nigerian government without compromising national security and human rights.
\end{abstract}

Keywords: Human Rights, National Security, Islamic Movement of Nigeria, Extremism

\subsection{INTRODUCTION}

From December 12 to 14, 2015 when the Nigerian Army carried out a massacre of 347 members of the Islamic Movement Nigeria (IMN) in Zaria, Kaduna State and buried the bodies of the victims in mass graves (Tangaza, 2019); there has been calls by civil society 
organisations, Human Rights lawyers and the international community on the need for the Federal Government of Nigeria (FGN) to respect human rights of its citizenry. While the government sees the group as a threat to national security obtaining a court order proscribing the group as a terrorist organistion, concerned stakeholders in the Human Rights community see the arrest and continued detention of the group leader, Sheikh Ibraheem Zakzaky by the Nigerian Police since December, 2015 as a big blow to human rights protection in Nigeria.

The Federal Government of Nigeria, for its part, sees the group, since 2015, as a terrorist, proIranian Shia group, with powers to unleash violence in the country. The government sees the group as an "enemy of the state", a threat to security and a violently aggressive group, unleashing mayhem against the Nigeria State, especially in Kaduna State. This position of government has pinned it against those who feel that the best approach to this security challenge is to allow the rule of law, due process and protection of the fundamental rights of Nigerians to movement and assembly to be respected as constitutionally provided for. This has brought to the fore, the relationship between protecting the national security interest of the Nigerian government and sovereignty on one hand; and preserving and guaranteeing the fundamental human rights of Nigerians.

The Nigerian government under President Muhammadu Buhari had banned the Islamic Movement of Nigeria (IMN) through a court proscription because the group "has been taken over by extremists who didn't believe in peaceful protests and instead employed violence to achieve its objectives" (Tangaza, 2019). From 2015 when the first known confrontation between the government and the group received media attention with the concern of the international community, protests by the group against the Nigeria government has remained unabated.

Dozens of IMN members were killed during a protest for the release of its leader Sheikh Zakzaky and wife Zeenah in Abuja. In the official website of IMN, it was reported that over fourteen (14) IMN members were killed in Kano, Sokoto, Gombe, Bauich etc. during the Ashura mourning processions staged across major cities in the Northern part of Nigeria on Tuesday $11^{\text {th }}$ of Muharam 1441; that is, September 10, 2019. The release by the court in Kaduna of Zakzuky and wife Zeenah to travel to India for medical attention and back without the purpose achieved, and the declaration by the Nigerian police, through IGP, Mohammed Adamu that "any person engaged or associating, in manner that could advance the activities of the proscribed Islamic Movement of Nigeria (IMN), shall be treated as a terrorist, enemy of the state, and a subversive element and shall be brought to justice". This had further compounded and complicated the crisis between the Nigerian government and the Islamic Movement of Nigeria (IMN) on the issues of Human Rights and National Security. Therefore, in order to critically and systematically discuss the challenges of human rights and national security in Nigeria vis-à-vis the Islamic Movement of Nigeria (IMN), this paper sets out to achieve the following objectives:

1. Determine the nature of national security and human Rights in Nigeria vis-à-vis the Islam Movement of Nigeria (IMN).

2. Determine the implications of the existence of the Islamic Movement of Nigeria (IMN) on national security and human rights.

3. Identify the contentious issues that tend to undermine national security and human right between the federal government and the Islamic Movement of Nigeria (IMN).

4. Make necessary recommendations on how these issues can be resolved without compromising citizens' rights, especially members of the Islamic Movement of Nigeria and national security. 
And to achieve these objectives, the sub-sections of this paper shall include introduction, conceptual clarifications, theoretical justification, national security and human rights in Nigeria vis-à-vis the Islamic Movement of Nigeria, contentious issues between the Nigerian State and the Islamic Movement of Nigeria (IMN), implications of the existence of Islamic Movement of Nigeria on national security and human rights in Nigeria and conclusion/recommendations

\subsection{Conceptual Clarifications}

National Security of Nigeria is part of some constitutional provisions of the 1999 Constitution of the Federal Republic of Nigeria (As Amended). Chapter II Section 14, Sub-section 1, 2a and b, under the "Fundamental Objectives and Directive Principles of State Policy of the 1999 constitution (as amended) states:

1) The Federal Republic of Nigeria shall be a state based on the principles of democracy and social justice (2) It is hereby, accordingly, declared that (a) sovereignty belongs to the people of Nigeria from whom government through this constitution derives all its powers and authority; (b) the security and welfare of the people shall be the primary purpose of the government.

The constitution recognizes that government exists primarily for the security of lives and property of citizens of a democratic state like Nigeria. Therefore, the provision of national security is the basis upon which the government of Nigeria derives its legitimacy from the people via the constitution.

Nevertheless, the Nigeria Police Force (NPF), under section 215, sub-section 3, of Part III in Chapter VI of the same constitution, confers on the "President or such other Minister of the Government of the Federation as he may authorise in that behalf, may give to the Inspector General of Police, such lawful directives with respect to the maintenance and security of public safety and public order as he may consider necessary, and the Inspector-General of Police shall comply with those directives or cause them to be complied with". The directives to comply with or ensure national security, is one that must be obeyed.

Furthermore, the Armed Forces of the Federation (Army, Navy and Air Force), according to the constitution (Section 217, sub-section 2 a-c) shall be equipped and maintained to be adequate and effective for the purposes of:

a) Defending Nigeria from external aggression

b) Maintaining its territorial integrity and securing its borders from violation on land, sea or air;

c) Suppressing insurrection and acting in aid of civil authorities to restore order when called upon to do so by the President, but subject to such conditions as maybe prescribed by an Act of the National Assembly.

This means the powers to curtail threats to national security are vested with the Nigerian Police and the Armed Forces of the Federation.

In a democracy like Nigeria, national security threats could come from terrorism, crime, insurgency, militancy, rebellion, insurrection and other concepts as economic, energy, environmental, food, cyber and political crimes. Sovereign states (not only Nigeria), protect their national security that forms part of their domestic and foreign policy. First, diplomatic, political, and economic measures are used in its enforcement. When this fails, military might is deployed to enforce and protect national security concerns. That was why the definition by 
Lasswell (1950) that national security is "freedom from foreign dictation" has been tagged "inadequate". There is always the protection of a nation's legitimate interest in the preservation of the greater good of the majority. This informed Lippman (1945) to define national security as, "when a nation does not have to sacrifice its legitimate interests to avoid war, and is able, if challenged, to maintain them by war".

All forms of aggression and insurrection, especially the perceived type posed by the Islamic Movement of Nigeria (IMN) against the Nigerian state with threat to peace, security stability and corporate existence of Nigeria politically, socially and economically, are threats against Nigeria's national security. This may have informed Harold Brown, a former Secretary of Defense, United State Department of Defense (USDD) in 1979 to define national security as; "the ability to preserve the nation's physical integrity and territory; maintain its economic relations with the rest of the world on reasonable terms; to preserve its nature, institution, and governance from disruption from outside; and to control its borders".

The Merriam Webster Dictionary (2019) defined Human Rights as, "rights (such as freedom from unlawful imprisonment, torture and execution) regarded as belonging fundamentally to all persons. The 1999 Constitution of Nigeria (as amended), in Chapter IV, Section 33 to 46, under "Fundamental Rights" states in section 33(1) that "every person has a right to life, and no one shall be deprived intentionally of his life, save in execution of the sentence of a court in respect of a criminal offence of which he has been found guilty in Nigeria".

The constitution recognises, in section 34 that, "every individual is entitled to respect for the dignity of the person, and accordingly, no person shall be subjected to torture or to inhuman or degrading treatments". However, in section 33 , sub-section 2 a to c, the constitution states:

A person shall not be regarded as having been deprived of his life in contravention of this section: if he dies as a result of the use, to such circumstances as are permitted by law, of such force as is reasonably necessary: a), for the defence of any person from unlawful violence or for the defence of property; b), in order to effect a lawful arrest or to prevent the escape of a person lawfully detained; or c), for the purpose of suppressing a riot, insurrection or mutiny.

Every citizen of Nigeria has the rights to life, dignity of the human person, personal liberty, fair hearing, private and family life, freedom of thought, conscience, religion, expression, press, movements, peaceful assembly, discrimination and property acquisition. The United Nations (2019) defined Human Rights as "rights inherit to all human beings, regardless of race, sex, nationality, ethnicity, language, religion, or any other status". These rights include the ones guaranteed by the constitution of Nigeria and most member countries. Human rights as universal laws were derived from the United Nations Charter on Human Rights adopted in 1945 by the General Assembly, and the Universal Declaration of Human Rights adopted in 1948.

The Universal Declaration of Human Rights (UDHR) proclaimed by the United Nations General Assembly in Paris on December 10, 1948, based on the General Assembly Resolution 217 A (III) "as a common Standard of achievements for all peoples and all nations", was aimed at universally protecting human rights of peoples and nations. Countries, including Nigeria have incorporated it into the national constitutions. The rights to life, liberty, freedom from slavery, torture, opinion, expression, association, work, education etc are universal rights that people of 
the world should enjoy. These rights also include economic, social, cultural, civil or political rights. These rights are enshrined in the 1999 Constitution of Nigeria (as amended). December 10 , every year is observed by the UN, as "Human Rights Day. The federal government of Nigeria has been accused of denying El-Zakzaky of his fundamental human rights. The killings of members for the Islamic Movement of Nigeria (IMN) have also been viewed as abuse of the rights of the group to assembly, religion and movement.

The Islamic Movement of Nigeria, (IMN) is both a religious and political organisation (Tangaza, 2019; Okakwu, 2018). IMN is headed in Nigeria by Sheikh Ibraheem Zakzaky, a Shia Muslim Cleric. Ideologically, IMN is an Anti-Zionist, Khomeinism and Shia Islamic group. It was founded in Nigeria in 1979 following the 1979 successful Iranian Revolution. Zakzaky, a Shia Muslim got his religious training in Iran and from 1990, established mass followership in Nigeria. IMN is also said to conduct most of its spiritual activities in Husainiyya Baqiyatullah, located in Zaria, Kaduna State, according to information obtained from its official website (IMN, 2019). The group also raised awareness about itself and advocates the liberation of the Palestinian territories occupied by Israel through street protest mostly in the Northern parts of Nigeria.

El-Zakzaky, the group leader is said to be influenced by Ayallah Khomeini, the Iranian Supreme Spiritual leader who led the revolution that overthrew the US-allied Shah in a popular uprising in 1979 (Tangaza, 2019; Abdullah, 2019). Khomeini has remained IMN main inspiration with absolute allegiance to him, then to Sheikh Zakzaky by over three million Shia members in Nigeria (IMN 2019). Tangaza (2019) in one of its BBC reports observed that IMN members do not recognize the authority of the Nigeria government, viewing Nigerian leaders (both Muslims and Christians) as corrupt and ungodly. It also has a registered foundation called "Fudiyya Foundation" that runs over 360 primary and secondary schools, hospitals, mosques and training centres. They command well educated members in the Civil Service, Army, and Police etc. The group has a Hezbollah like guard corps, a newspaper, official website and mass followership for protestation.

Shia Muslims are those who followed the leadership of Ali, the son-in-law of Prophet Muhammad who died in the early $7^{\text {th }}$ century. Opposed to the Shias are the Sunnis, who backed the father-in-law of Prophet Muhammad, Abu Bakr. The Sunnis are in the majority with its headquarters in Saudi Arabia. The Shias are mostly in Iran. The division between the Sunni and Shia Muslims dates back to the battle on who succeeds Prophet Mohammed in the $7^{\text {th }}$ century AD.

With respects to national security and human rights| in Nigeria vis-à-vis the Islamic Movement of Nigeria (IMN), the Nigeria army had an altercation with the group in 2015 when the group, in procession on a religious function in Zaria, Kaduna State was alleged to have tried to kill its Chief of Staff who was driving through. The army's retaliation led to the death of over 350 IMN members and hundreds of arrests. The group leader, Sheikh El-Zakzaky and his wife were arrested and in December, 2016, after one year, charged with murder, manslaughter, unlawful assembly and disruption of public peace, charges he pleaded "not guilty".

\subsection{Theoretical Justification}

The Islamic Movement of Nigeria (IMN) is accusing the government of Nigeria at the state and federal levels of victimisation, abuse of the fundamental rights of its members and unlawful detention of its leader and other members, killings, disruption of its religious activities, injustice and selective targeting and proscription as a terrorist group in order to undermine its existence as a Shia Muslim sect in Nigeria. On the other hand, the government of Kaduna State and the Federal Government of Nigeria had accused the group and its leader of being societal 
deviants, threat to natural security, and terrorist organisation with murderous and aggressive characterisation which undermine peace, security, unity and corporate existence of the Nigerian state. On what theoretical discourse can these two arguments justified?

Professor Murray Bowen (1913-1990), a Psychiatrist and former Professor of Psychiatry at Georgetown, University had, in his "Family Theory in Clinical Practice" (1966) attributed the family as an emotional unit, and that 'any change in emotional functioning of one member of the family' (emotional unit), is predictably and automatically compensated for by changes in the emotional functionality of other members of that family or emotional unit. The Family Theory, as used, could explain why people who formed a group or are knitted together in a group by circumstances, formed an emotional unit, with an agreed way of indoctrination such that, any change or changes in the emotional functionality of one member of the group (family), affects all other members of the group. The Islamic Movement of Nigeria (IMN) as a group is seen as a family (emotional unit), whose members' beliefs are against the requirements of unity, solidarity, peace, law and order according to the federal government of Nigeria (Ebhomele, 2019). This has created a non-conformist challenge between the government of Nigeria and the Islamic Movement of Nigeria (IMN). Before the writings and theory of Professor Bowen, the individual, according to or previously thought by traditional Psychology, was the basic unit of emotional functionality. With the "Family Theoryl" by Professor Bowen, the narrative changed to the family as the basic unit of emotional functionality where respect to societal norms, constituted civic authority or deviant behaviors are formed and conformity stressed. Deviant behaviours, especially radicalisation by extremists, are also inculcated in the families. Extremists use family units to indoctrinate the emotional functioning of individuals. And seen as a group (family), it is by far "the most potent and time-tested agent of socialisation of individuals in all known human societies" (Wesley, 2001). Religious radicalism, indoctrination and extremism are perpetuated by religious leaders using the family as the emotional unit for religious fundamentalism. Such leaders create political and religious ideologies; inculcating non-tolerant, non-conformist societal deviant mindsets on young people, thereby exacerbating the challenges of insecurity in the society.

Gurr (1970) had argued that the potential causes of social movements and deviance that lead to extreme situations such as political violence, religious extremism and social instability such as rioting, terrorism, civil wars, crimes etc. were products of unhealthy indoctrination of perceived societal deprivation. Functionalist theorists also argued that "all social institutions are organised to provide for the needs of the society" (Akubo, 2015). The needs of the society are presented to individuals in the society through the family. The union of families (groups) helps to ensure a standard of behaviour whether in conformity with the society or against the society. Families or groups response aggressively through actions that are antagonistic to the values of the society when a sense of futility and conviction arises to the fact that the society cannot carter for their needs; This is why the "Family Theory" is very important in threats groups as family units posed on societal insecurity. On the part of governments, deviation from the principle of conformity especially government sanctioned behaviours is seen as threat to national security, peace and corporate unity. Certain sections of the 1999 constitution especially Section 35, Sub-section 1a to d are cited to curtail the exercise of the constitutional guaranteed respect for personal liberty; "upon reasonable suspicion of his having committed a criminal offence, or to such extent as may be reasonably necessary to prevent his committing a criminal offence...". Even when the constitution does not permit long detention which undermines respect for fundamental human rights, threat to national security is used mostly to suppress freedom and liberty of individuals. The conflict between the Nigerian government and the Islamic Movement of Nigeria (IMN) on the twin issues of national security and human 
rights could be seen from the perspective of family's (group) emotional consciousness and societal acceptable behavioural conformity to aggregate emotional consciousness.

\subsection{Islamic Movement of Nigeria (IMN), National Security and Human Rights in Nigeria}

Islamic Movement of Nigeria (IMN) has accused the government of Nigeria of human rights abuses (Adebayo, 2019). The group's leader, El-Zakzaky who was arrested on December, 2015 has been in detention since. Several court orders for his release on bail has not been heeded or complied with by the federal government (Abddullah, 2019). On Monday August 05, 2019, a court in Kaduna granted Ibrahim Zakzaky permission to travel to India for medical treatment. A week later, he was returned lack to what the government called "protective custody" along with his wife. He faces charges of culpable homicide and unlawful assembly along with his wife. Protestation against his "unlawful" and continuous detention by the government against court orders of his release has trailed his arrest since 2015.

In 2018, Amnesty International reported that 45 people died and 122 were injured in clashes between the Nigerian Army and the Shiites protesters in the capital city of Abuja (Abdullah, 2019). On July this year, several people, including a senior Police Officer, and a journalist (Youth Corp Member), were also killed during clashes between IMN members and security forces (IMN, 2019; Adebago, 2019; Tangaza, 2019; and Abdullah, 2019). A blame game has continued to undermine the true position of the law, rule of law, due process, national security and human rights with respect to this issue. The government obtained a court order in 2018 and proscribed the group as a terrorist organisation whose practices undermined national security, peace, unity and corporate existence of Nigeria.

For the part of the group, the established family consciousness and solidarity have propelled an unabated resolve to protest against the injustices meted out against them and the continued detention of their leaders. In a statement in July, 2019, the President of the media group of IMN, Ibrahim Musa, the group, in justifying its continued protest against the fundamental rights abuses of its members noted:
...it is not possible under every logical reasoning to exonerate President Muhammadu Buhari from the genocide perpetrated by the Nigerian Army under his command as Commander-in-Chief, where over 1,000 unarmed members of the movement including men, women and children were killed on $12^{\text {th }}-14^{\text {th }}$ of December, 2015. The government has declared illegally burying 347 members of the movement in a mass grave at Mando Village in Kaduna after the mass murder, in violation of Geneva Convention, and every known law in the country... (Okakwu, 2018).

The Federal Government of Nigeria through the Senior Special Adviser on Media and Publicity, Garba Shehu has maintained that El-Zakzaky is standing trial in Kaduna, and "government at the centre can be said to be clear of any alleged violations of court orders trumpeted every day" (Okakwu, 2018). While the IMN has continued to also call for the implementation of the Judicial Commission of Inquiry whose report called for the arrests and prosecution of soldiers that perpetrated the killing of peaceful protesting members of IMN in Zaria in 2015; government has insisted that the group existence and activities are serious threats to national security, as such, members' fundamental rights cannot be guaranteed. 


\subsection{Contentious Issues between the Nigerian State and the Islamic Movement of Nigeria}

On December 14, 2015, Sheikh Zakzaky and his wife were arrested by the Nigerian Army after a confrontation during a religious procession with the convoy of the Chief of Army Staff, Lt. Gen. Turkur Buratai, was perceived as life threatening. The convoy and orderlies of the Chief of Army Staff accused IMN members of "explosion, firing and stoning" of the Army Chief and his convoy in Zaria during their procession (Tangaza, 2019). The army retaliated by demolishing the headquarters of the group's religious worship centre, killed 347 of its members and arrested many including Sheikh El-Zakzaky and his wife.

Similarly, on December 2, 2016, a Federal High Court in Abuja ordered the release from what the government called "protective custody" of Zakzaky and his wife, citing the violation, through continued detention, of Section 35, Sub-section 1 a to d of the 1999 constitution of Nigeria (as amended). The Federal Government of Nigeria in collaboration with the Kaduna State government filed charges of murder, manslaughter, unlawful assembly and disruption of public peace against the group (Tangaza, 2019).

From 2015 to date, the leader of the Islamic Movement of Nigeria (IMN) and his wife have been in "protective custody" without been granted bail. The demand for his release and respect for his freedom has also continued unabated for the past four years by concerned lawyers and members of the group (Okakwu, 2019; Abdullah, 2019). On April 18, 2015 the Kaduna State government also filed fresh eight-court charges on the leader of IMN, including capable homicide which is punishable in Nigeria law by death. Barrister Femi Falani, Sheikh ElZakzaky's lawyer, in acknowledging the new charges, appealed to the Nigerian government to release the Shiites leader and his wife on bail to stand trail in order to avoid the likelihood of a fresh insurgency in Nigeria since the Nigerian legal system presumes a person innocent until proven guilty in a court of competent jurisdiction (Okakwu, 2018; Abdulah, 2019).

In keeping the Shiites Leader and his wife on "protective custody", the federal government of Nigeria accused the group of unleashing violence and being an "enemy of the state" (Tangaza, 2019). The government also obtained a court judgment proscribing the group as a terrorist organization, justifying the ban on the ground that the group's activities as a religious group "has been taken over by extremists who didn't believe in peaceful protests and instead employed violence to achieve its objectives" (Tangaza, 2019). The IMN denied being behind the violence, and also accused security forces of killing innocent and peaceful protesters. The Nigerian Police Force, through the Inspector General (IGP) Mohammed Adamu, insisted that people who engaged or associate with the IMN in any manner seen to have directly or indirectly advanced the cause of the group as a proscribed terrorist group, would be treated as a terrorist group, an enemy of the state and a subversive element and would be brought to face the full wrath of the law and justice.

Most recently, the court granted bail to the Shiites leader for medical treatment and travel to India along with his wife. Zakzaky was said to have had a partial stroke while in prison with deteriorating health. His wife Zeenat was also said to have needed to undergo a knee cap replacement and have since been in detention while the issues of national security and human rights continue to dominate public discourse in respect to Shiekh El-Zakzaky's case.

\subsection{Implications of Sheikh El-Zakzaky Continued Detention on National Security and Human Rights in Nigeria.}

The primary responsibility of government is the security and welfare of the people. This is the Fundamental Objectives and Directive Principles of State Policy as enshrined in the 1999 constitution of the Federal Republic of Nigeria (as amended) in Chapter II, Sections 14, Sub- 
section 1 and 2 . The constitution also recognised that sovereignty belongs to the people, from where governments in Nigeria draw legitimacy from. Furthermore, Chapter IV, Sections 33 to 46 of the constitution; the fundamental rights of Nigerian citizens were guaranteed, protected and preserved. Nevertheless, Section 33 of the constitution, based on national security, peace, orderliness and sustenance of the corporate existence of Nigeria curtailed the freedoms and liberties of Nigerians that the same constitution protected.

Arising from the foregoing especially when national security is viewed from the angle of "comprising the personal and communal state of being secured from a wide range of critical and pervasive threats including, but not limited to all forms of violence, injustice and violation of human rights" (Vande, 2019, pp. 2-5). This means national security encompasses respect for people's rights, liberty and freedom. Jeopardising these rights is antithetical to national security and people's sovereign power. Insecurity, extremism etc. strive when there are protracted conflicts; inhuman treatment of victims of terrorist attacks; human rights violations; discrimination; marginalisation and poor governance (Ugwueze, et al, 2018). Soft approaches, accountability and inclusiveness through compromise and other dispute resolution mechanism that build trust, mutual solidarity, understanding and love, are preferable to military might and crackdown of non- conformist groups to acceptable societal norms and values.

The estimated three million Shiites who have been labeled "terrorists" through a legal process of proscribing their activities in Nigeria are seen as societal deviants. This implies that terrorists, especially known ones co-habit with citizens in Nigeria. This negative labelling is capable of undermining the existing peace and security in Nigeria. The federal government crackdown on the Shia Muslim group is also seen by some groups and individuals as a religious battle of supremacy between the Sunni Muslim group backed by Saudi Arabia, and the Shia Muslim group backed by Iran.

This is dangerous to religious harmony and peaceful coexistence of a country like Nigeria with religious diversity. The death of three sons of Sheikh Zakzaky and his eldest sister in the military raid of his home in 2015 (Tangaza, 2019), his continued incarceration, and the proscription of the IMN as a terrorist organization are capable, if not well managed, of undermining Nigeria's corporate unity and existence.

In 2009, in Maiduguri, Borno State, over 700 people were killed during a bloody confrontation between Boko-Haram sect and the Nigeria military. The leader of the group, Mohammed Yusuf was arrested and extra-judicially killed in Police custody. Ten years later, the Armed Conflict Location and Event Data Project (ACLED) had recorded over 3, 340 incidents or attacks, 37, 530 deaths and 2.4 million people displaced as at December, 2018. These attacks by the Boko Haram group have also left 7 million people at the risk of starvation in a continued and very potent insurgency war. This is a lesson of history that should not be repeated. The educated nature of IMN notwithstanding, a Boko-Haram style insurgency can be avoid if national security is not used as a pretext to undermine the fundamental rights of members and continuous killings and destruction of their property.

Human Rights Watch (HRW) Nigeria, speaking through one of its researcher and representative in Nigeria condemned the ban as it "threatens the basic human rights of all Nigerians, may portend an even worse security force crackdown on the group, which could have dire human rights implications throughout Nigeria" (Tangaza, 2019). Cardinal John Onaiyekan was also quoted to have told a Vatican Radio that "nobody is safe" in Nigeria. "Today it's the Shia, tomorrow it could be us Catholics too". Protests have also been held in Tehran, 
Iran and other countries. President Hassan Rouhani of Iran had phoned President Buhari of Nigeria on the crackdown, killings and detention of Shiites leader and members. These have had huge security, political, economic, social, religious and international policies and relationship implications which the Nigerian government is enjoined to make critical evaluation and consciously take a decision that aligned national security with respect of human rights of the citizenry.

\subsection{Conclusion and Recommendations}

National security and human rights of citizens are constitutional provisions that should be respected. The preservation and protection of the sovereignty and territorial integrity of the Nigerian state against external aggression and internal insurrection should be done without compromising the fundamental rights of the citizens. When there is a perceived deviant behaviour or non-conformist societal norms and values by a group, through emotional functioning that are aligned with a given religious indoctrination, crackdown, abuse of human rights of members, killings and detention of the group's members do not eradicate such emotional functioning. Fear of discrimination and victimisation increased religious and emotional indoctrination of group members. Due process, rule of law, constitutionalism and adherence to judicial pronouncements should underscore government approach to the assumed threat to national security by members of the Islamic Movement of Nigeria (MN).

With a difficult challenge confronting government to maintain a strong national identity in Nigeria devoid of ethnicity and religion, and agitations for secession and resource control with insurgency and militancy used as weapons to undermine national unity, cohesion and peaceful coexistence, efforts of government should be geared towards soft approaches, accountability and inclusiveness through compromise in resolving conflicts for national security, stability, peace, prosperity and sustainable development especially in the provisions of citizens' welfare in the areas of education, health, social security and sustainable livelihood.

Based on the forgoing therefore and the need to maintain justice, freedom and liberty of Nigerians including IMN members without undermining national security, the following recommendations are put forward:

1. The Federal Government of Nigeria should as a matter of urgency consider the detention of Sheikh El-Zakzaky and his wife Zeenat for over four years as national security threat that undermines respect for human rights in Nigeria. There should be a legally binding mutual compromise between the IMN group represented by their lawyer, Femi Falana (SAN) and the federal government represented by the Minister of Justice and Attorney-General of the federation, Abubakar Malami, on the need to release the Shiites leader and his wife on bail, provide him with good medical attention and allow him come from home to face trial. This will restore confidence in citizens who are questioning the place of human rights in Nigerian democracy. The law should be respected, and due process within the rule of law obeyed and observed in processes of litigation and judicial adjudication and arbitration.

2. There is no doubt that the continued crackdown and killings of the members of the Islamic Movement of Nigeria (IMN) have social, economic, political, religious and security implications. The government of Nigeria should not continue to assume ignorance of these implications. People have the rights to social security and freedom of association and assembly. Citizens have the rights to economic freedom and sustainability through social security and equal economic opportunity devoid of victimization, discrimination and suppression. People have the rights to followership of leaders with charismatic competence for quality representation that promotes unity and solidarity. People also have the rights to religious freedom, worship and value 
orientation. The protection of these constitutionally guaranteed rights constitute national security in the spirit and letters of the constitution. There is need for government to respect these rights for all members of the Nigerian State, including the Islamic Movement of Nigeria (IMN) members. Discrimination should not be encouraged, condoned or sanctioned by the Nigerian state against individuals or group within the country.

3. Insurgency in the Northern part, insurrection in the Eastern parts, and aggression in the Western part of Nigeria has lessons of history. These agitations arose as rebellion against the Nigerian state because of military crackdown, proscription and perceived victimization. The Federal Government of Nigeria should consider dialogue pursued to its logical conclusion in order to reach a truce with the IMN group. Peace is costly; its maintenance is even much costlier. There is the need for out-of-court settlement that could promote a win-win situation between the government and the IMN group. Proscribing the group as a terrorist group would only fuel hatred, create instability, oil religious and ethnic indoctrination and hatred against the Nigerian government. Dialogue and compromise should be applied to resolve this issue.

4. Abuse of people's fundamental rights and travesty of justice occur when someone is detained without trial for four years. The Shiites leader and his wife have been in detention long enough to warrant daily protestation by IMN members. Without a speedy trial and a compromise, democratic freedom, justice and fairness will be seen to have been denied. Faith in democracy, human rights and the judiciary will also be undermined. There is the need to ensure possibly through a directive by the Chief Justice of Nigeria (CJN) that the trial of Sheikh El-Zakzaky should immediately commence and rounded up in December this year. This is to ensure that in four years (December, 2015 to December, 2019) a little progress in the judicial stagnation would have been achieved. Citizens' continued denial of justice and judicial conformity with Section 35 of the 1999 constitution (as amended) amount to totalitarian democracy and dictatorship in a democratic society. This paper recommends the unconditional release of the Shiites leader without further delay and his trial commenced immediately.

\section{References}

Abdullah, T. (2019, July 22). Nigeria is violating Constitution on the El-Zakzaky and Dasuki cases. African Liberty News Report. Retrieved September 21, 2019, from www.africanliberty.com

Adebayo, B. (2019, August 5). Nigeria's Shiites leader granted medical leave pending trial. Cable News Network $(C N N)$. Retrieved September 21, 2019, from www.cnn.com

Akubo, J. (2015). Family decadence and terror ties in Nigeria, the North-East example. African Social and Educational Journal, Faculty of Business Administration, 4(2).

Bowen, M. (1996). The use of family theory in clinical practice. Journal of Comprehensive Psychiatry. 7(5), 345374.

Brown, H. (2007). National Security. Department of Defense Dictionary of Military and Associated Terms, Manuel, July 12. Retrieved May 30, 2019.

Ebhomele, E. (2019, August 19). Presidency discloses reason El-Zakzaky is still in detention. Legit New online. Retrieved September 21, 2019, from www.legit.ng.

Gurr, T. (1970). Why Men Rebel; Princeton: Princeton University Press

Okakwu, E. (2018, April 26). Detained Nigerian Shiites leader El-Zakzaky charged with murder. Premium Times Online New. Retrieved September 20, 2019, from www.premiumtimesng.com. 
Tangaza, H.S. (2019, August 5). Islamic Movement in Nigeria: the Iranian-Inspired Shia Group. BBC-Africa News. Retrieved September 20, 2019 from www.bbc.com

Ugwueze, M. et. al. (2018). Complicity of the Nigerian state in organized crimes: a critique of security governance. A Journal Publication of the Nigerian Political Science Association, 7,(242-257). Retrieved May 30, 2019 from www.npsanigeria.org.

United Nations. (2019). Human Rights. Retrieved September 20, 2019, from www.un.org.

Vande, P.T. (Ed.) (2019). State and National Security in Nigeria. The State Politics and Development, Essays in Honour of Professor Eme Ekekwe. Port Harcourt: University of Port Harcourt Press, pp. 284-301.

Wesley, H. (2001). Redefining Family System Therapy. New York. Prentice Hall Publishers. 